\title{
Cleavable Hydrophilic Linker for One-Bead-One-Compound Sequencing of Oligomer Libraries by Tandem Mass Spectrometry
}

\author{
Margot G. Paulick, ${ }^{\dagger}$ Kathryn M. Hart, Kristin M. Brinner, Meiliana Tjandra, \\ Deborah H. Charych,* and Ronald N. Zuckermann*, \\ Chiron Corporation, 4560 Horton Street, Emeryville, California 94608
}

Received November 1, 2005

\begin{abstract}
We have developed a method for the rapid and unambiguous identification of sequences of hit compounds from one-bead-one-compound combinatorial libraries of peptide and peptoid ligands. The approach uses a cleavable linker that is hydrophilic to help reduce nonspecific binding to biological samples and allows for the attachment of a halogen tag, which greatly facilitates post-screening sequencing by tandem mass spectrometry (MS/MS). The linker is based on a tartaric acid unit, which, upon cleavage from resin, generates a C-terminal aldehyde. This aldehyde can then be derivatized with a bromine-containing amino-oxy compound that serves as an isotope tag for subsequent MS/MS analysis of y-ion fragments. We have applied this linker and method to the syntheses of a number of peptoids that vary in sequence and length and have also demonstrated single-bead sequencing of a peptoid pentamer. The linker is also shown to have very low levels of nonspecific binding to proteins.
\end{abstract}

\section{Introduction}

Chemical libraries produced by combinatorial synthesis have become powerful tools in the search for high-affinity protein ligands, drug candidates, and new materials. Combinatorial chemistry allows for the rapid synthesis of a large collection of diverse molecules. ${ }^{1}$ The majority of the compound libraries that have been prepared to date have been synthesized using high-yielding general reactions and solidphase synthesis techniques. The solid phase facilitates the handling of large numbers of reactions, allowing the use of excess reagents and simple washing procedures to isolate the desired product. But in the case of one-bead-onecompound (OBOC) libraries, the solid phase can also be used as a surface to display ligands to be screened against a desired soluble target.

Lam and co-workers demonstrated that an entire beadbound library can be assayed against a wide variety of labeled biological targets to discover novel protein ligands. ${ }^{2,3}$ Onbead screening assays offer several advantages over solutionbased screening: (1) very large numbers of compounds can be screened as on-bead assays are very rapid (taking only a few hours to screen $10^{7}-10^{8}$ beads), (2) the color/ fluorescence intensity of the bead is generally proportional to the affinity of the ligand, thus allowing a simple qualitative assessment of the $K_{\mathrm{D}}$ for the protein-ligand complex, (3) the bead library may be used multiple times for different

\footnotetext{
* To whom correspondence should be addressed. E-mail: deb_charych@ chiron.com (D.H.C.); ron@ ronznet.com (R.N.Z.).

$\dagger$ Current address: Department of Chemistry, University of California, Berkeley, CA 94720.

$\doteqdot$ Current address: Department of Chemistry, Massachusetts Institute of Technology, Cambridge, MA 02139.

$\S$ Current address: Biological Nanostructures Laboratory at The Molecular Foundry, Lawrence Berkeley National Laboratory, 1 Cyclotron Road, Berkeley, CA 94720.
}

(a)

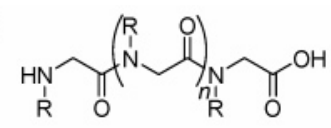

(b)

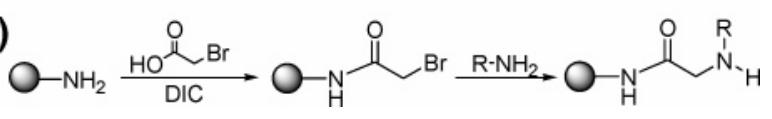

Figure 1. (a) Structure and (b) submonomer synthesis of a peptoid oligomer. DIC $=$ diisopropylcarbodiimide.

protein targets, and (4) the beads allow rapid discovery of high-affinity multivalent ligands. ${ }^{4}$ The on-bead screening approach has been successfully applied to the identification of ligands for a large number of biological targets..$^{5-10}$

Limitations of the on-bead screening format include the requirement for soluble targets and nonspecific adsorption of the sample onto the solid phase, confounding the analysis of protein binding. The need for soluble targets is a drawback for drug discovery, but this does not detract from the search for novel ligands for diagnostic or proteomics applications, where the target is usually a soluble protein and the ligand is immobilized. Nonspecific adsorption issues have been managed by the use of hydrophilic beads (e.g., TentaGel) that accommodate both the synthesis and screening conditions.

Efforts in our lab and in other labs have focused on the preparation of combinatorial libraries of peptoids, $\mathrm{N}$-substituted glycine oligomers that are a versatile and synthetically accessible heteropolymer that show promise in drug discovery, proteomics and diagnostics (Figure 1). ${ }^{11}$ Peptoids can be synthesized using a solid-phase submonomer synthesis protocol that is based on a two-step monomer addition cycle. This cycle is highly efficient and can generate peptoids that contain up to 48 monomer units. ${ }^{12}$ Hundreds of monomers that span a wide variety of side-chain functionalities can be 
readily incorporated into peptoids. ${ }^{13,14}$ Peptoid oligomers are protease-resistant ${ }^{15}$ and have also been shown to bind to a variety of cellular receptors with high affinity. ${ }^{16-19}$ On the basis of these properties, peptoids are ideally suited for the preparation of large, chemically diverse combinatorial libraries, as can be seen by the recent synthesis of a peptoid hexamer library containing more than 500000 compounds. $^{7}$

Although the biological screening of OBOC libraries is extremely efficient, the structural determination of the library components can be time-consuming, especially for large peptide or peptoid libraries. ${ }^{20-23}$ Direct sequencing on resin by Edman degradation is often used to identify these compounds; however, only 3-4 peptoids or peptides can be sequenced each day with an automated peptide/peptoid microsequencer. ${ }^{3,5,7,8,24,25}$ Analysis of unnatural amino acids by Edman degradation is especially slow, since it requires the synthesis and analysis of standards for each unnatural residue. ${ }^{25}$ Although Edman degradation has been used to identify peptoid sequences, only 24 different monomers have been characterized by this approach. ${ }^{7,26}$ Chemical encoding methods obviate the need for sequencing, but the coding tags can interfere with the binding of protein to the target compound, and also require extra synthetic steps to construct the coding tag. ${ }^{27-43} \mathrm{~A}$ common limitation of all coding systems is that they are indirect.

Mass spectrometry (MS) offers both high sensitivity and efficiency for the structural determination of combinatorial peptoid libraries. $^{21-23,44-48}$ Tandem MS (MS/MS) is routinely used to determine the sequence of peptides. ${ }^{49}$ Liskamp and co-workers have analyzed peptoids by tandem MS and have shown that, like peptides, the sequence of a peptoid can readily be determined from its MS/MS spectrum. ${ }^{50-52}$ HPLC and tandem MS allow for the direct assessment of the purity and identity of the compounds in the peptoid library. The direct analysis of the ligand on each bead eliminates any confusion about the purity and structure of the compound.

To analyze the compound on a single bead, one must be able to cleave the library compound from the resin bead and accurately and rapidly sequence the residues by assigning the appropriate $\mathrm{y}$ - and b-ions in the MS/MS spectrum. In this paper, we describe a method that allows for the rapid analysis of combinatorial peptoid or peptide libraries followed by single-bead MS/MS sequencing (Scheme 1). This approach uses a hydrophilic cleavable linker to avoid the undesired nonspecific binding that is likely with a hydrophobic linker. The linker is based on a tartaric acid unit that allows for the cleavage of the compound to give a $\mathrm{C}$-terminal aldehyde, which can then be derivatized with a brominecontaining amino-oxy compound that serves as an isotope tag for subsequent MS/MS analysis of y-ion (C-terminal) fragments. With this method, the structure of a hit compound can be determined rapidly and directly from the compound itself on a single bead.

\section{Results and Discussion}

Linker Design and Synthesis. To develop a method to identify the sequence of hit compounds resulting from onbead screening, it is important that the resin and linker be compatible with both the synthesis and screening conditions.
Scheme 1. Rapid Sequencing of One-Bead-One-Compound Combinatorial Libraries by Tandem Mass Spectrometry Using a Cleavable Hydrophilic Linker ${ }^{a}$

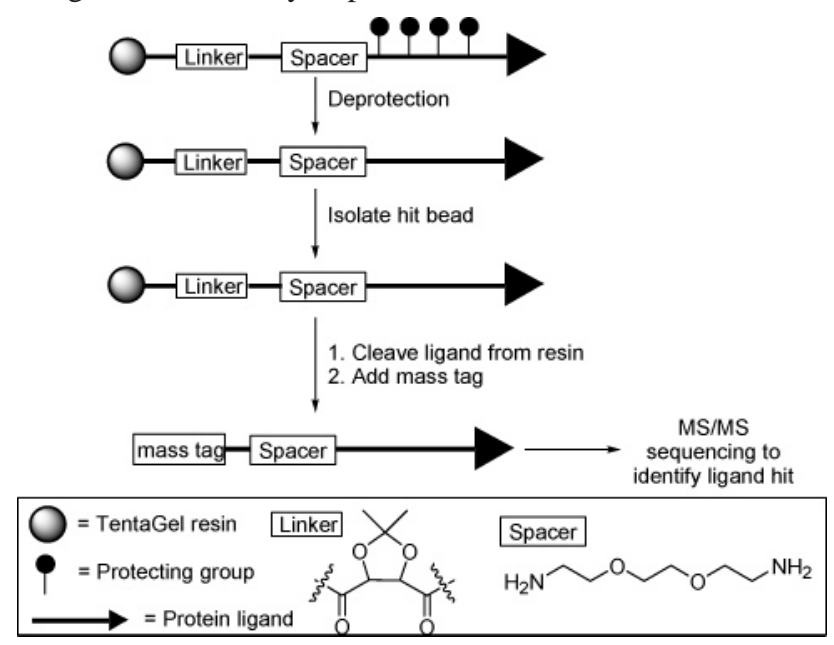

${ }^{a}$ After on-bead synthesis, protecting groups are removed without cleavage of the compound from the resin. Compounds are cleaved from the resin and derivatized with a mass tag. MS/MS sequencing of the ligand is facilitated by the unique isotope pattern of the mass tag.

The resin employed in these assays must have the following properties: (1) compatibility with both synthetic procedures and biological assays, such that the beads can be used in both library synthesis and screening with protein targets, (2) a linker that allows for the deprotection of peptide/peptoid side chains without the release of the compound from resin but also allows for eventual cleavage of the compound from resin, (3) a sufficiently high loading capacity so that the sequences of hit compounds from a screen can be determined unambiguously by rapid MS/MS-based sequencing of a single bead, and (4) a method to assign peaks from the MS/ MS spectrum rapidly and accurately.

Kodadek and co-workers have recently developed an onbead screening approach in which fluorescently labeled proteins bind to peptoids on biocompatible TentaGel resin in an aqueous solution. ${ }^{7}$ TentaGel Macrobeads (280-320 $\mu$ m diameter from Rapp Polymere) consist of a hydrophobic polystyrene core derivatized with poly(ethylene glycol) chains. ${ }^{65}$ These beads have good swelling properties in both organic and aqueous solvents and are mechanically robust. In addition, the poly(ethylene glycol) chains provide a surface that resists nonspecific protein binding. ${ }^{53}$ On the basis of these favorable properties, TentaGel Macrobeads were chosen for our method. ${ }^{66}$

Standard peptide and peptoid synthesis linkers require strong acid to simultaneously deprotect the side chains and release the compound from the resin. On-bead screening assays, on the other hand, require the removal of these protecting groups without cleavage of the testing compound from the resin. Edman sequencing does not require a linker, as the sequencing is done with release of the oligomer from the resin. ${ }^{3,5,7,8,24,25}$ However, for MS/MS analysis, the library compound must be released into solution. Many linkers were considered, but in the interest of reducing background protein binding, we chose hydrophilic linker 7 (Figure 2).

Melnyk and co-workers have developed a tartaric acidbased linker that allows for the cleavage of a compound from 


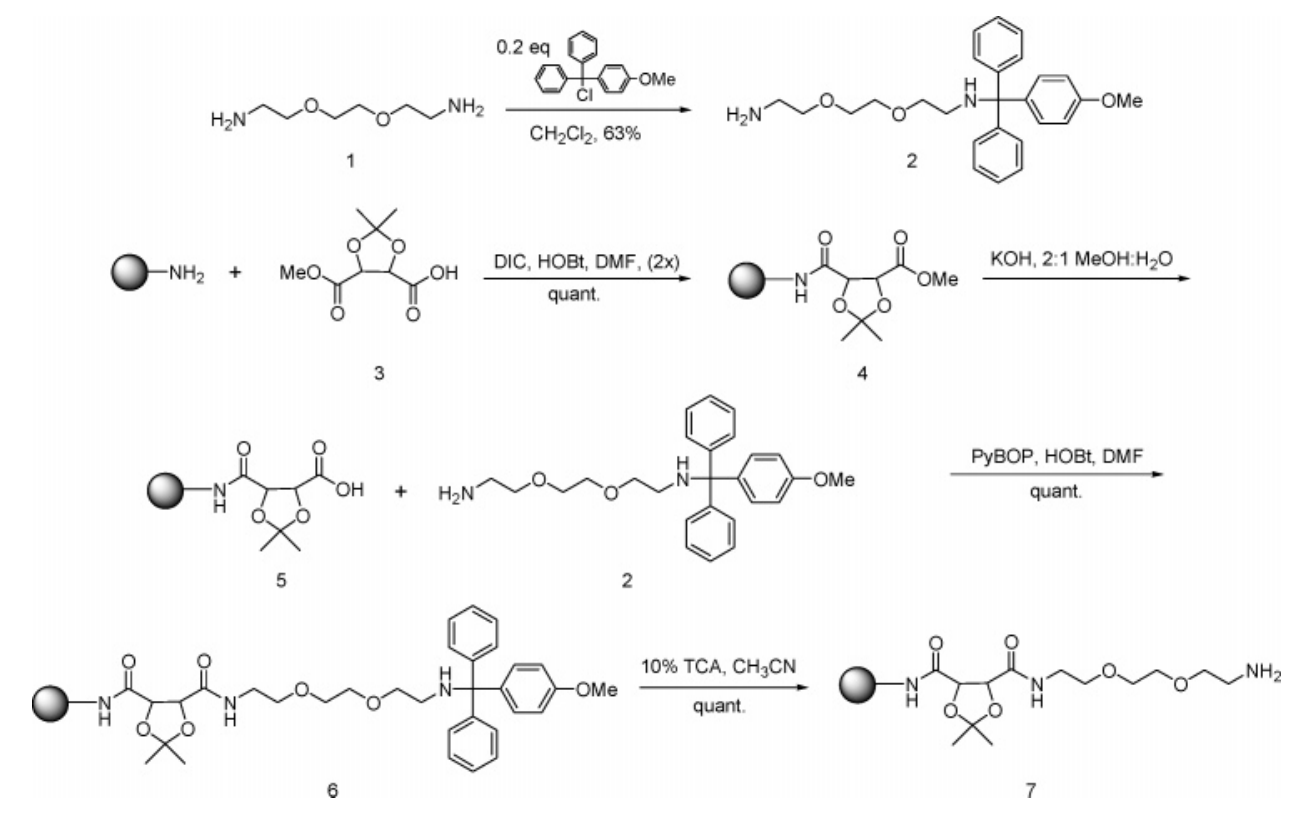

Figure 2. Structure and synthesis of tartaric acid-based hydrophilic linker 7.

resin using periodate oxidation..$^{54,55}$ These cleavage conditions are orthogonal to trifluoroacetic acid (TFA) side-chain deprotection conditions and also generate a C-terminal aldehyde upon cleavage from resin. This aldehyde can then be derivatized chemoselectively with a number of reagents, including hydrazines and amino-oxy compounds. In our approach, the aldehyde produced upon cleavage is reacted with a bromine-containing amino-oxy compound, which provides a diagnostic isotopic pattern for subsequent analysis of MS/MS fragmentation y-ions.

We have modified the structure of the tartaric-acid based linker synthesized by Melnyk and co-workers to contain a short ethylene glycol spacer. This spacer moves the testing compound further away from the bead and should also resist nonspecific protein binding. The structure and synthesis of resin $\mathbf{7}$ is shown in Figure 2. Diamine $\mathbf{1}$ was selectively monoprotected by slow addition of $p$-anisylchlorodiphenyl methane in methylene chloride at room temperature to yield amine $\mathbf{2}$. We originally tried a 2-nitrobenzenesulfamide protecting group for the diamine but found that this group was difficult to remove quantitatively. $(2 R, 3 R)-2,3$-di- $O$ isopropylidenetartaric acid monomethyl ester $3^{56}$ was coupled to TentaGel- $\mathrm{NH}_{2}$ Macrobeads using $N, N^{\prime}$-diisopropylcarbodiimide (DIC) and 1-hydroxybenzotriazole (HOBt) as activating agents. After coupling, methyl ester $\mathbf{4}$ was hydrolyzed with $\mathrm{KOH}$ in methanol, activated with PyBOP and HOBt, and then coupled to amine 2 to give resin $\mathbf{6}$. The yield of this coupling reaction was found to be nearly $100 \%$, on the basis of a quantitative ninhydrin test. Finally, the amine protecting group was removed from resin $\mathbf{6}$ using a solution of trichloroacetic acid in acetonitrile. The loading of resin 7 was determined to be $0.15 \mathrm{mmol} / \mathrm{g}$, as determined by quantitative ninhydrin analysis. This resin was used in subsequent peptoid oligomer syntheses.

Test Peptoid Pentamer. To evaluate the compatibility of the hydrophilic linker with solid-phase synthesis, we chose to synthesize a simple test peptoid pentamer (10) on resin 7 (Figure 3). After solid-phase synthesis on resin 7, the peptoid-

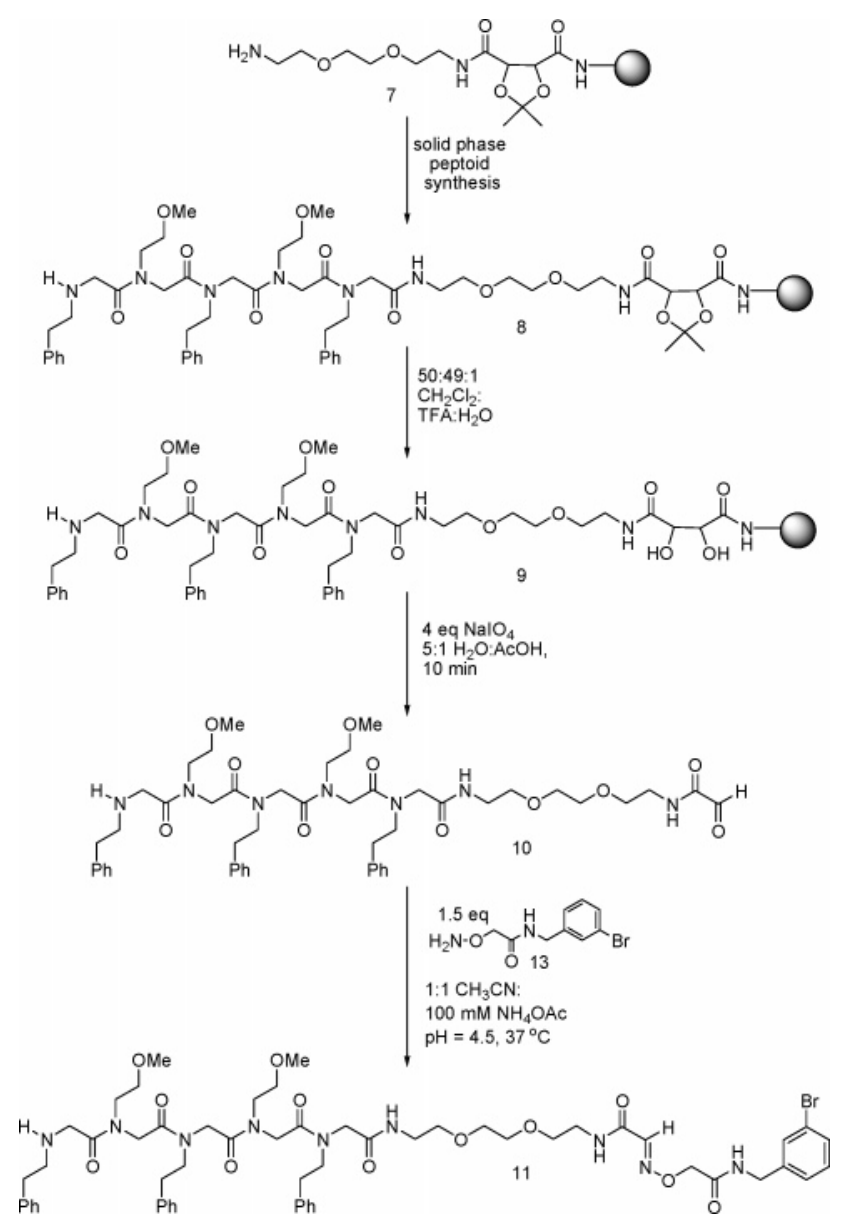

Figure 3. Synthesis, oxidative cleavage, and oxime formation to generate test pentamer peptoid oxime $\mathbf{1 1}$.

containing resin $\mathbf{8}$ was subjected to acetonide cleavage, using a cleavage cocktail of 50:49:1 methylene chloride/ TFA/water $(\mathrm{v} / \mathrm{v} / \mathrm{v})$, to generate free diol 9. The diol was then oxidatively cleaved with $\mathrm{NaIO}_{4}$ in 5:1 water/acetic acid (v/v) for $10 \mathrm{~min}$ to give the free aldehyde peptoid 10. Excess periodate was quenched with dimethyl sulfide, and the peptoid pentamer was purified by HPLC and isolated in a $60 \%$ yield. 
It is known that aldehydes react specifically and rapidly with amino-oxy compounds to generate oximes. ${ }^{57-59} \mathrm{We}$ chose to derivitize the peptoid containing a C-terminal aldehyde with a bromine-containing amino-oxy compound to serve as an isotope tag. The mass spectrum of a brominecontaining compound has a distinct isotopic pattern because of the relative abundances of bromine isotopes. Therefore, the fragment peaks corresponding to the $\mathrm{C}$-terminus of the peptoid pentamer (y-ions) can be easily identified by their characteristic isotope cluster, greatly simplifying the analysis of unknown compound fragments.

Isotopic labeling has been used to facilitate the identification of relevant MS signals for both combinatorial library synthesis and protein sequencing. ${ }^{60-64}$ Watson and coworkers have developed a deuterium-containing solid-phase linker that they have applied to the structural analysis of a library of small molecules by electrospray (ESI)-MS.62 Chlorine- and bromine-containing tags have also been used to encode a small molecule combinatorial library ${ }^{63,64}$ MALDI-FTMS analysis of the coding tags allowed for the determination of the structures of the library members. In an excellent example demonstrating the power of isotopic labeling, Lehmann and co-workers digested cytokeratin 8 in ${ }^{18} \mathrm{O}$-enriched water (containing both $\mathrm{H}_{2}{ }^{16} \mathrm{O}$ and $\mathrm{H}_{2}{ }^{18} \mathrm{O}$ ) ${ }^{60}$ These conditions generated protein fragments containing both ${ }^{16} \mathrm{O}$ and ${ }^{18} \mathrm{O}$ at their $\mathrm{C}$-termini, which could be further fragmented by ESI-MS/MS. The C-terminal fragment ions (y-ions) were readily discriminated from the $\mathrm{N}$-terminal fragment ions (b-ions) on the basis of their unique isotopic doublet pattern, resulting from the incorporation of ${ }^{18} \mathrm{O}$ only at the C-terminus.

For our isotopic mass tag, we chose a simple structure, 13, a bromine-containing amino-oxy compound. This compound was generated from Boc(aminooxy) acetic acid and 3-bromobenzylamine. Peptoid aldehyde $\mathbf{1 0}$ was then incubated with isotope tag 13 at $37{ }^{\circ} \mathrm{C}$ (Figure 3). On the basis of HPLC and MS analysis, the reaction quantitatively produced peptoid oxime 11. The peptoid pentamer oxime 11 was then analyzed by MALDI q-TOF MS and MS/MS. As can be seen in Figure 4a, the MS/MS spectrum of oxime $\mathbf{1 1}$ is easy to interpret: the peptoid fragments along the amide bonds and the y-ions can be identified unambiguously based on the bromine isotope pattern. There are very few extraneous fragments to complicate the spectral analysis (the three other major peaks below $\mathrm{m} / \mathrm{z}=560$ correspond to b-ions). Table 1 lists the expected and observed masses of the y-ions for compound 11. We also synthesized the same peptoid pentamer on Rink Amide resin, which produces a C-terminal amide (14) upon cleavage from resin. The MS/MS spectrum of the peptoid with a C-terminal amide $\mathbf{1 4}$ (Figure 4b) is complicated by more fragment ions, and it cannot immediately be discerned if a fragment peak is a y-ion or a b-ion. The situation is expected to worsen with increasing oligomer length. A comparison of the MS/MS spectrum of amide 14 with oxime 11 revealed that the oxime compound fragments more cleanly and allows for the immediate identification of y-ion peaks, leading to the rapid and accurate determination of the peptoid's sequence.

Peptoid Pentamers: Increased Side Chain Complexity. Given the successful synthesis and analysis of a simple
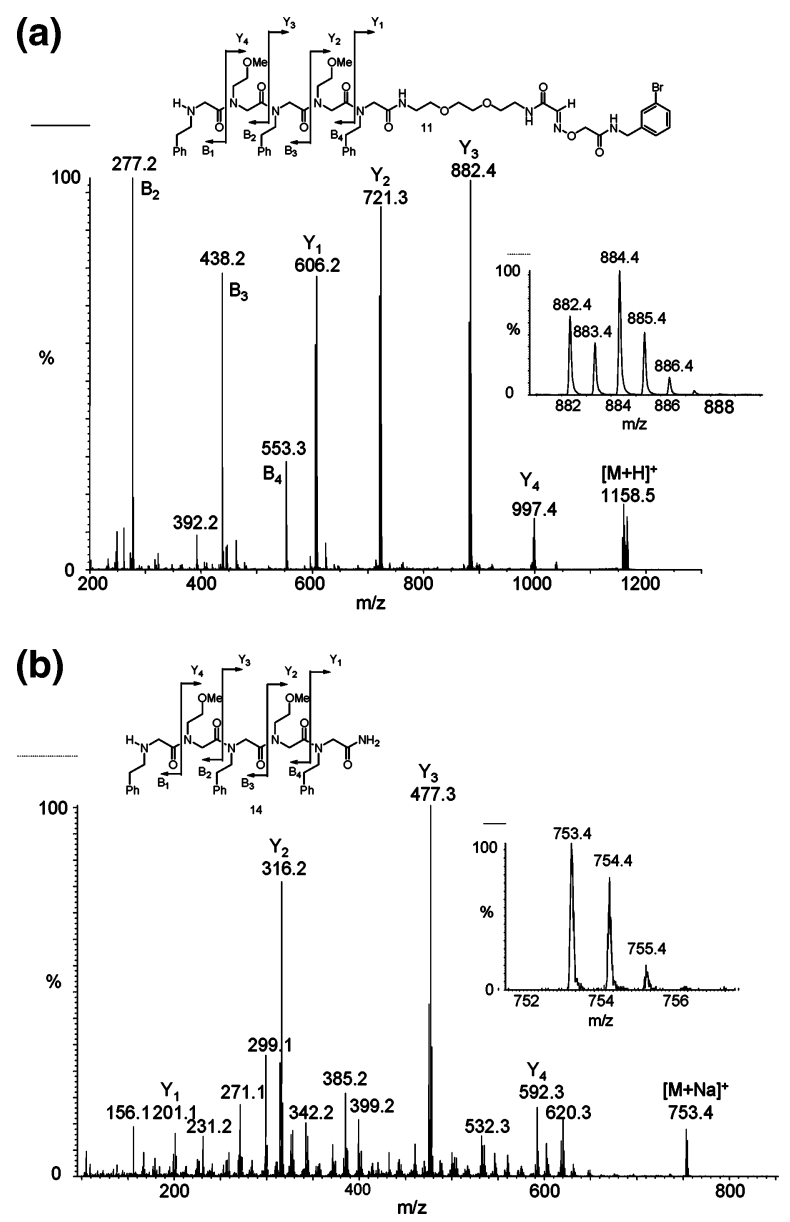

Figure 4. (a) MS/MS spectrum of pentamer peptoid oxime 11 The $\mathrm{y}$ - and $\mathrm{b}$-ions are annotated. Inset shows the unique isotope pattern of the bromine-containing $\mathrm{Y}_{3}$ ion. (b) Structure and MS/ MS spectrum of pentamer peptoid amide 14. Inset shows the lack of a characteristic isotope pattern for the $[\mathrm{M}+\mathrm{Na}]^{+}$ion. The y-ions are annotated (no b-ions were observed).

Table 1. Expected and Observed y-Ion Masses from the MS/MS Analysis of Peptoid Pentamer Oxime 11

\begin{tabular}{ccc}
\hline fragment ion & calcd $m / z^{a}$ & obsd $m / z^{a}$ \\
\hline $\mathrm{Y}_{5}$ & 1158.49 & 1158.50 \\
$\mathrm{Y}_{4}$ & 997.41 & 997.41 \\
$\mathrm{Y}_{3}$ & 882.34 & 882.35 \\
$\mathrm{Y}_{2}$ & 721.26 & 721.26 \\
$\mathrm{Y}_{1}$ & 606.20 & 606.20 \\
\hline
\end{tabular}

${ }^{a} \mathrm{~m} / \mathrm{z}$ ratios are for the monoisotopic species.

pentamer sequence, we next turned to more complex sequences. We chose to include a diverse set of monomers containing hydrophobic, acidic, basic, and cyclic side chains (Figure 5a). Many of these monomers require side-chain protection, but all of the protecting groups used can be removed with TFA during acetonide deprotection of the tartrate moiety on the linker. After they were periodate cleaved and coupled with amino-oxy compound 13, crude peptoid pentamers $\mathbf{1 5}-\mathbf{2 0}$ were analyzed by MALDI q-TOF MS and MS/MS. Table 2 lists the calculated and observed $\mathrm{y}$-ions for these peptoid oximes. The MS/MS spectrum for peptoid oxime $\mathbf{1 5}$ is shown in Figure 5b. As seen before with peptoid pentamer oxime 11, the MS/MS spectrum of oxime $\mathbf{1 5}$ is easy to interpret: the peptoid fragments along the amide bonds and the y-ions can be easily identified. All 
(a)

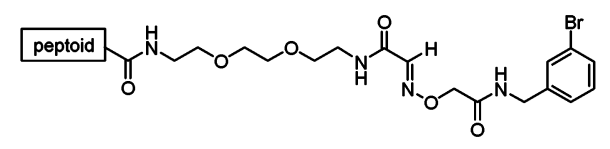

15: Nme-Nffa-Nme-Nbu-Nme

16: Nme-Nap-Nme-Ncpe-Nme

17: Nme-Nser-Nme-Ndpe-Nme

18: Nme-Nphos-Nme-Ntyr-Nme

19: Nme-Ncm-Nme-Ntrp-Nme

20: Nme-Nbse-Nme-Npe-Nme

21: Nme-Npe-Nme-Npe-Nme-Npe-Nme-Npe-Nme-Npe

22: Nme-Ntyr-Nme-Npe-Nme-Ncpe-Nme-Ntrp-Nme-Nbu

23: Ncpe-Npe-Nap-Nme-Ncm-Npe-Nbu-Nme-Nser-Npe

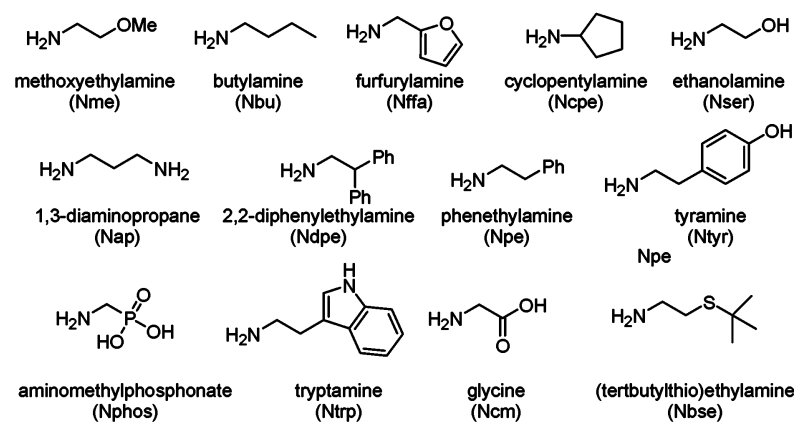

(b)

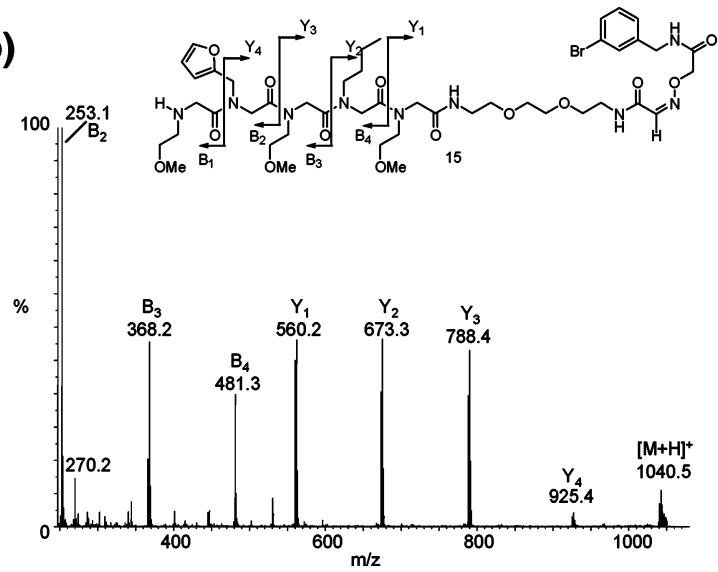

Figure 5. (a) Structures of oxime-containing peptoids $\mathbf{1 5}-\mathbf{2 3}$ and the amines used for their preparation. (b) MS/MS spectrum of pentamer peptoid oxime 15. The $y$ - and b-ions are annotated.

of the peptoid pentamers synthesized were cleaved from the resin and cleanly converted to the oxime, except for the thioether-containing peptoid pentamer 20 (Table S1). The thioether moiety was quantitatively oxidized during cleavage to the sulfoxide moiety. However, this reaction would occur after the on-bead protein-binding assay and can be readily accounted for during sequencing analysis by the addition of the mass of oxygen.

Peptoid 10-mers. We next applied our approach to the synthesis of longer peptoid oximes with diverse side chains.
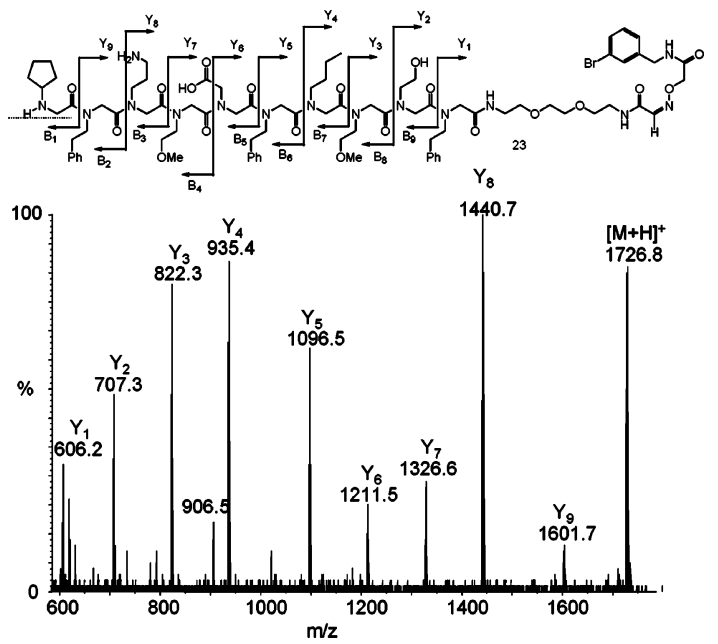

Figure 6. MS/MS spectrum of 10-mer peptoid oxime 23. The $\mathrm{y}$-ions are annotated.

Oxime-containing peptoid 10-mers (compounds 21-23) are shown in Figure 5a. After they were periodate cleaved and coupled with amino-oxy compound 13, the crude peptoid 10-mers were again analyzed by MALDI-qTOF MS and MS/ MS. Table 3 lists the calculated and observed y-ions for peptoid oximes 21-23. As seen with the pentamer peptoid oximes, the MS/MS spectrum of oxime $\mathbf{2 3}$ is straightforward to interpret: the y-ions can be easily identified (Figure 6). The crude peptoid 10-mers were not as pure as the crude peptoid 5-mers (Table S2), yet the MS/MS spectra of the crude 10-mers were still easy to interpret. Therefore, this method is readily applicable even to longer crude peptoids.

Single Bead MS/MS Analysis. To use this method to determine the sequence of hit compounds from OBOC combinatorial libraries, the quantity of oxime peptoid obtained after cleavage from a single bead must be sufficiently high to allow for MS/MS. Therefore, the loading of the compound on resin and the subsequent cleavage and ligation efficiencies must be high. To evaluate this approach for single bead MS/MS analysis, a single bead loaded with the test peptoid pentamer, 10, was picked and subjected to periodate cleavage and reaction with the amino-oxy isotope tag 13. The cleavage and oxime-forming reactions yielded pure product despite the small quantity of material (Figure 7). The amount of peptoid pentamer oxime isolated was about $1.3 \mathrm{nmol}$, which corresponds to a yield of $58 \%$ based upon resin loading. A single bead provided more than enough material for both MS/MS and HPLC analysis, if necessary. On the basis of these results, we conclude that this linker

Table 2. Expected and Observed y-Ion Masses from the MS/MS Analyses of Peptoid Pentamer Oximes 15-20 Containing Complex Side Chains

\begin{tabular}{ccccccccccc}
\hline $\begin{array}{c}\text { peptoid } \\
\text { oxime }\end{array}$ & $\begin{array}{c}\mathrm{Y}_{5} \text { calcd } \\
m / z^{a}\end{array}$ & $\begin{array}{c}\mathrm{Y}_{5} \text { obsd } \\
m / z^{a}\end{array}$ & $\begin{array}{c}\mathrm{Y}_{4} \text { calcd } \\
m / z^{a}\end{array}$ & $\begin{array}{c}\mathrm{Y}_{4} \text { obsd } \\
m / z^{a}\end{array}$ & $\begin{array}{c}\mathrm{Y}_{3} \text { calcd } \\
m / z^{a}\end{array}$ & $\begin{array}{c}\mathrm{Y}_{3} \text { obsd } \\
m / z^{a}\end{array}$ & $\begin{array}{c}\mathrm{Y}_{2} \text { calcd } \\
m / z^{a}\end{array}$ & $\begin{array}{c}\mathrm{Y}_{2} \text { obsd } \\
m / z^{a}\end{array}$ & $\begin{array}{c}\mathrm{Y}_{1} \text { calcd } \\
m / z^{a}\end{array}$ & $\begin{array}{c}\mathrm{Y}_{1} \text { obsd } \\
m / z^{a}\end{array}$ \\
\hline $\mathbf{1 5}$ & 1040.44 & 1040.50 & 925.37 & 925.43 & 788.32 & 788.38 & 673.26 & 673.31 & 560.17 & 560.21 \\
$\mathbf{1 6}$ & 1029.46 & 1029.46 & 914.40 & 914.41 & 800.32 & 800.32 & 685.26 & 685.26 & 560.17 & 560.17 \\
$\mathbf{1 7}$ & 1128.46 & 1128.42 & 1013.40 & 1013.37 & 912.35 & 912.32 & 797.29 & 797.25 & 560.17 & 560.15 \\
$\mathbf{1 8}$ & 1118.38 & 1118.34 & 1003.32 & 1003.29 & 852.32 & 852.29 & 737.25 & 737.22 & 560.17 & 560.15 \\
$\mathbf{1 9}$ & 1105.42 & 1105.39 & 990.36 & 990.34 & 875.33 & 875.31 & 760.27 & 760.24 & 560.17 & 560.15 \\
$\mathbf{2 0}^{b}$ & 1140.47 & 1140.44 & 1025.41 & 1025.40 & 836.32 & 836.29 & 721.26 & 721.23 & 560.17 & 560.14 \\
\hline
\end{tabular}

${ }^{a} \mathrm{~m} / \mathrm{z}$ ratios are for the monoisotopic species. ${ }^{b}$ All of the fragments containing Nbse had the mass of oxygen added to them because of formation of the sulfoxide. 
Table 3. Expected and Observed y-Ion Masses from the MS/MS Analyses of Peptoid 10-mer Oximes 21-23 with Complex Side Chains

\begin{tabular}{lrrrrrr}
\hline & $\begin{array}{c}\text { 21 calcd } \\
m / z^{a}\end{array}$ & $\begin{array}{c}\text { 21 obsd } \\
m / z^{a}\end{array}$ & $\begin{array}{c}\text { 22 calcd } \\
m / z^{a}\end{array}$ & $\begin{array}{c}\text { 22 obsd } \\
m / z^{a}\end{array}$ & $\begin{array}{c}\text { 23 calcd } \\
m / z^{a}\end{array}$ & $\begin{array}{c}\text { 23 obsd } \\
m / z^{a}\end{array}$ \\
\hline $\mathrm{Y}_{10}$ & 1825.85 & 1825.88 & 1796.85 & 1796.79 & 1726.81 & 1726.82 \\
$\mathrm{Y}_{9}$ & 1710.78 & 1710.75 & 1681.79 & $b$ & 1601.73 & 1601.73 \\
$\mathrm{Y}_{8}$ & 1549.70 & 1549.76 & 1504.71 & 1504.73 & 1440.64 & 1440.67 \\
$\mathrm{Y}_{7}$ & 1434.64 & 1434.67 & 1389.65 & 1389.67 & 1326.56 & 1326.57 \\
$\mathrm{Y}_{6}$ & 1273.55 & 1273.59 & 1228.56 & 1228.59 & 1211.50 & 1211.54 \\
$\mathrm{Y}_{5}$ & 1158.49 & 1158.53 & 1113.50 & 1113.56 & 1096.47 & 1096.52 \\
$\mathrm{Y}_{4}$ & 997.41 & 997.43 & 988.42 & 988.43 & 935.39 & 935.41 \\
$\mathrm{Y}_{3}$ & 882.34 & 882.37 & 873.35 & 873.38 & 822.31 & 822.33 \\
$\mathrm{Y}_{2}$ & 721.25 & 721.28 & 673.26 & 673.30 & 707.24 & 707.26 \\
$\mathrm{Y}_{1}$ & 606.20 & 606.22 & 558.19 & 558.20 & 606.20 & 606.21 \\
\hline
\end{tabular}

${ }^{a} \mathrm{~m} / \mathrm{z}$ ratios are for the monoisotopic species. ${ }^{b} \mathrm{Y}_{9}$ ion abundancy is too low to observe.

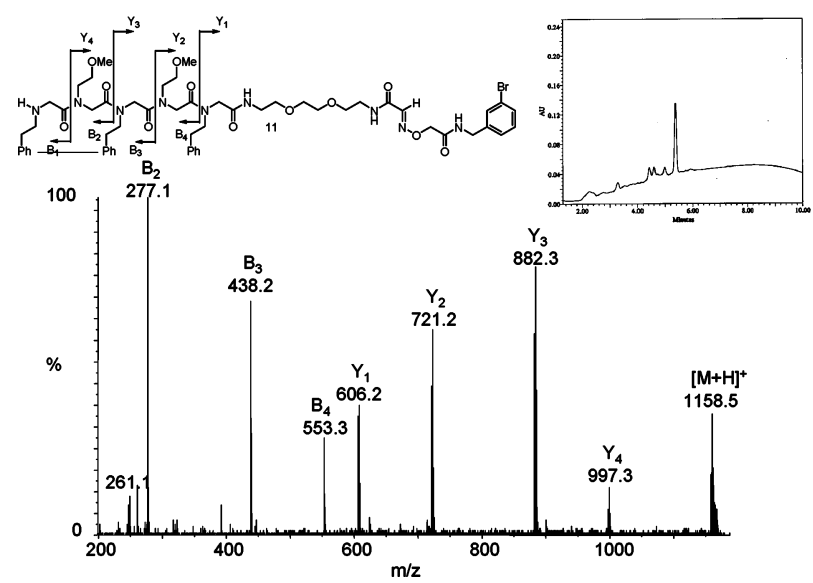

Figure 7. MS/MS spectrum of pentamer peptoid oxime $\mathbf{1 1}$ from a single-bead cleavage. The $y$ - and b-ions are annotated. Inset shows the HPLC analysis of the final conjugate.

and sequencing method can be applied to the rapid screening of OBOC combinatorial peptide or peptoid libraries.

Nonspecific Protein Binding. In an on-bead screening assay, it is important to minimize the amount of nonspecific protein absorption to both the beads and linker. In designing our approach, we chose to use TentaGel Macrobeads and synthesized a linker that is devoid of hydrophobic groups to reduce background protein binding. To evaluate nonspecific protein binding, we incubated acetylated resin $\mathbf{7}$, as well as a variety of other acetylated resins, with a mammalian cell lysate (MV522 and NCI H82 cells), and compared the amount of protein that bound nonspecifically to these surfaces. The resins compared were as follows: (1) acetylated polystyrene Rink Amide resin, (2) acetylated TentaGel Rink Amide resin, (3) acetylated TentaGel- $\mathrm{NH}_{2}$ resin, and (4) acetylated resin 7. Rink Amide resin allows for the cleavage of compounds from resin using TFA and is often used in combinatorial library synthesis. The Fmoc protecting groups were removed from these resins, and all of the resins were capped at their amino termini with an acetate moiety. The absence of peptoids allowed the assessment of nonspecific protein binding solely to the base resin and linker components.

The resins were swelled and incubated with lung cell lysate from MV522 and NCI H82 cells, which provides a realistic complex protein mixture. After incubation, the resins were

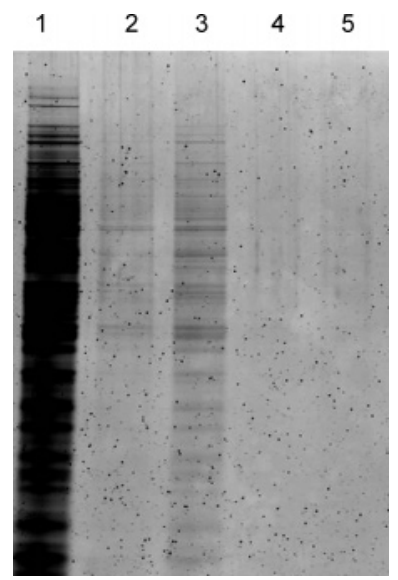

Figure 8. SDS-PAGE gel of nonspecific protein binding to different resins and linkers. Lane 1: lung cell lysate from CMV522 and NCI82 cells. Lane 2: lysate eluted from acetylated polystyrene Rink Amide resin. Lane 3: lysate eluted from acetylated TentaGel Rink Amide resin. Lane 4: lysate eluted from acetylated TentaGel$\mathrm{NH}_{2}$ resin. Lane 5: lysate eluted from acetylated resin 7.

washed, and any bound proteins were then eluted and analyzed by SDS-PAGE (Figure 8). Both polystyrene Rink Amide and TentaGel Rink Amide resins bound proteins nonspecifically. Rink Amide-containing resins contain a large hydrophobic moiety that may promote nonspecific protein adsorption. Surprisingly, polystyrene Rink Amide resin bound less protein nonspecifically than the TentaGel Rink Amide resin under these conditions. This may be due to the minimal swelling of polystyrene in aqueous solution, reducing the surface area of resin available for protein binding. Neither TentaGel- $\mathrm{NH}_{2}$ resin nor resin 7 showed any nonspecific protein adsorption. On the basis of this experiment, we conclude that linker $\mathbf{7}$ is suitable for on-bead screening of proteins because it resists nonspecific protein binding, even in the presence of a complex protein mixture.

\section{Conclusion}

We have described a new method that allows for rapid tandem MS sequencing of hit compounds isolated from onbead protein screening of combinatorial oligomer libraries. This approach uses a tartaric acid-based hydrophilic linker that enables cleavage of the compound from resin to give a C-terminal aldehyde. Furthermore, the aldehyde can be derivatized with a bromine-containing amino-oxy compound that serves as an isotope tag for subsequent MS/MS analysis of y-ion fragments. This results in a significant simplification of the spectrum, making interpretation of the sequence very straightforward. We have applied this approach to the synthesis and sequencing of a number of peptoids that vary in side chain functionality and length. The loading of the peptoids on the linker-modified TentaGel resin is sufficiently high to allow single-bead sequencing by MS/MS of a peptoid pentamer. Finally, the linker-modified resin also resists nonspecific protein binding. Although we have specifically applied this method to peptoid oligomers, the approach can be readily adapted to peptides.

This tagging method can be used to determine the structure of a hit compound from an OBOC combinatorial library directly from the compound itself, eliminating the need for 
coding tags or for time-consuming Edman sequencing. This method can be coupled to the synthesis of OBOC libraries and on-bead biological screening to generate a highthroughput procedure for the discovery and identification of novel peptoid and peptide ligands. Only beads that test positive for protein-binding ligands are chosen for MS sequencing. The number of positive hits is generally a small percentage of the total number of library members, therefore the method is anticipated to be highly efficient for those hits. Currently, we are using this linker and tagging method in on-bead screening assays to discover novel oligomers from combinatorial peptoid libraries.

\section{Experimental Section}

Unless otherwise noted, all reactions were performed under a nitrogen atmosphere. Solvents and reagents were obtained from commercial suppliers and used without further purification. Distilled water was used in all chemical manipulations. TentaGel- $\mathrm{NH}_{2}$ Macrobeads (substitution $0.21 \mathrm{mmol} / \mathrm{g}$ ) and TentaGel Rink Amide resin (substitution $0.18 \mathrm{mmol} / \mathrm{g}$ ) were obtained from Rapp Polymere (Tübingen, Germany). Polystyrene Rink Amide resin (substitution $0.57 \mathrm{mmol} / \mathrm{g}$ ) was obtained from NovaBiochem (Läufelfingen, Switzerland). Thin-layer chromatography (TLC) was carried out using silica gel plates $60 \mathrm{~F}_{254}$. TLC plates were visualized using ceric ammonium molybdate, ninhydrin, potassium permanganate, or absorbance of UV light. ${ }^{1} \mathrm{H}$ and ${ }^{13} \mathrm{C}$ NMR spectra were acquired on a Varian Mercury $300 \mathrm{MHz}$ spectrometers. All ${ }^{1} \mathrm{H}$ and ${ }^{13} \mathrm{C}$ NMR spectra are reported in $\delta$ relative to tetramethylsilane. Signals are reported as $\delta$ (multiplicity, coupling constants, \#H). Multiplicities are abbreviated as follows: $\mathrm{s}=$ singlet, $\mathrm{d}=$ doublet, $\mathrm{t}=$ triplet, $\mathrm{q}=$ quartet, $\mathrm{m}=$ multiplet, $\mathrm{br}=$ broad, and app $=$ apparent. Electrospray $($ ESI+) mass spectra were obtained on a Hewlett-Packard 1100 MSD series electrospray system in the positive mode with a $50 \mathrm{~V}$ cone voltage. Analytical HPLC was performed on a Waters 2690 system (equipped with a photodiode array detector) with a C4 reversed-phase HPLC column (Duragel $\mathrm{G}, 3 \mu \mathrm{m}, 300 \mathrm{~A}, 0.2 \times 5.0 \mathrm{~cm}$ ). A linear gradient elution of $5-95 \% \mathrm{~B}$ in $10 \mathrm{~min}$ was used at a flow rate of $0.8 \mathrm{~mL} / \mathrm{min}$ and a column temperature of $60{ }^{\circ} \mathrm{C}$ (solvent $\mathrm{A}=0.1 \%$ TFA in water, solvent $\mathrm{B}=0.1 \%$ TFA in acetonitrile). MALDI q-TOF MS and MS/MS spectra were obtained on an Applied Biosystems Q-Star XL modified with a Ciphergen PCI 1000 ion source for MALDI and SELDI. Peptoids were spotted onto SEND ID Arrays (Ciphergen) with $1 \mu \mathrm{L}$ of a $10 \mathrm{mg} /$ $\mathrm{mL}$ CHCA ( $\alpha$-cyano-4-hydroxycinnamic acid) MALDI matrix.

2-[2-(2-\{[(4-Methoxy-phenyl)-diphenyl-methyl]-amino\}ethoxy)-ethoxy]-ethylamine (2). To a stirring solution of $\mathrm{K}_{2} \mathrm{CO}_{3}(13.13 \mathrm{~g}, 95.0 \mathrm{mmol}$ ) and 2,2'-(ethylenedioxy)-bis(ethylamine) $(69.36 \mathrm{~mL}, 475 \mathrm{mmol})$ in dichloromethane (543 $\mathrm{mL}$ ) was added a solution of $p$-anisylchlorodiphenyl methane $(29.34 \mathrm{~g}, 95.0 \mathrm{mmol})$ in dichloromethane $(90 \mathrm{~mL})$. The mixture was allowed to stir under $\mathrm{N}_{2}$ for $3 \mathrm{~h}$ at room temperature and then concentrated in vacuo. The residue was dissolved in dichloromethane, washed with saturated $\mathrm{NaH}-$ $\mathrm{CO}_{3}(2 \times 200 \mathrm{~mL})$, dried over $\mathrm{Na}_{2} \mathrm{SO}_{4}$, filtered, and concentrated. The residue then was purified by silica gel chromatography, eluting with 10:1:0.1 dichloromethane/ methanol/ $/ \mathrm{NH}_{4} \mathrm{OH}$ to yield $25.3 \mathrm{~g}(63 \%)$ of 2 as a yellow oil. ${ }^{1} \mathrm{H}$ NMR $\left(\mathrm{CDCl}_{3}, 300 \mathrm{MHz}\right): \delta 7.49-7.16(\mathrm{~m}, 12 \mathrm{H})$, $6.82(\mathrm{~m}, 2 \mathrm{H}), 3.76(\mathrm{~s}, 3 \mathrm{H}), 3.57(\mathrm{~m}, 8 \mathrm{H}), 2.84(\mathrm{t}, 2 \mathrm{H}, J=$ $5.1 \mathrm{~Hz}), 2.60(\mathrm{br} \mathrm{s}, 2 \mathrm{H}), 2.36(\mathrm{t}, 2 \mathrm{H}, J=5.4 \mathrm{~Hz}) .{ }^{13} \mathrm{C} \mathrm{NMR}$ $\left(\mathrm{CDCl}_{3}, 100 \mathrm{MHz}\right): \delta 158.1,146.6,138.5,130.3,129.8$, 129.1, 128.6, 128.3, 73.5, 71.5, 70.5, 70.4, 54.9, 54.4, 43.3, 41.6. LRMS (ESI+): $\mathrm{m} / \mathrm{z}$ calcd for $\mathrm{C}_{26} \mathrm{H}_{32} \mathrm{~N}_{2} \mathrm{O}_{3} \mathrm{Na}^{+}[\mathrm{M}+$ $\mathrm{H}^{+}$] 443.2, found 443.6.

Protected Linker 4. TentaGel- $\mathrm{NH}_{2}$ Macrobeads (100 g, $0.21 \mathrm{mmol} / \mathrm{g}, 21 \mathrm{mmol}$ ) were swelled in $500 \mathrm{~mL}$ DMF for $20 \mathrm{~min}$. The solvent was drained and a solution of $\mathbf{3}$ (21. 44 g, $105 \mathrm{mmol})$, HOBt (14.19 g, $105 \mathrm{mmol})$, and DIC (16.44 $\mathrm{mL}, 105 \mathrm{mmol})$ in dry DMF (525 mL) was added to the resin. This suspension was allowed to react with gentle shaking for an hour at room temperature, after which the solution was drained, and a fresh solution of $\mathbf{3}(21.44 \mathrm{~g}$, $105 \mathrm{mmol})$, HOBt (14.19 g, $105 \mathrm{mmol})$, and DIC (16.44 $\mathrm{mL}, 105 \mathrm{mmol})$ in dry DMF $(525 \mathrm{~mL})$ was added. This suspension was allowed to react with gentle shaking for 18 $\mathrm{h}$ at room temperature. The solution was drained, and the resin was washed with DMF $(4 \times 500 \mathrm{~mL})$. The yield of the coupling reaction was found to be nearly $100 \%$, based on a quantitative ninhydrin test. The charge of resin $\mathbf{4}$ was determined to be $0.15 \mathrm{mmol} / \mathrm{g}$. Although the TentaGel- $\mathrm{NH}_{2}$ $\mathrm{MB}$ resin was labeled as $0.21 \mathrm{mmol} / \mathrm{g}$, this substitution was not confirmed by repeated ninhydrin assays. Loading was determined to be closer to $0.15 \mathrm{mmol} / \mathrm{g}$.

Capping and Deprotection of Resin 4 (5). Resin 4 (100 $\mathrm{g}, 0.15 \mathrm{mmol} / \mathrm{g}, 15 \mathrm{mmol})$ was swelled in DMF (500 mL) for $20 \mathrm{~min}$. The solvent was drained, and a solution of acetic anhydride $(18.9 \mathrm{~mL}, 200 \mathrm{mmol})$ and pyridine in DMF (500 $\mathrm{mL}$ ) was added to the beads. The suspension was allowed to react with gentle shaking for half an hour at room temperature. The solution was drained, and the beads were washed with DMF $(4 \times 500 \mathrm{~mL})$. The resin was then swelled in $2: 1 \mathrm{MeOH} / \mathrm{H}_{2} \mathrm{O}(500 \mathrm{~mL})$ for $20 \mathrm{~min}$. The solution was drained, and a solution of $\mathrm{KOH}(5.89 \mathrm{~g}, 105 \mathrm{mmol})$ in 2:1 $\mathrm{MeOH} / \mathrm{H}_{2} \mathrm{O}(525 \mathrm{~mL})$ was added to the beads. This suspension was allowed to react with gentle shaking for $17 \mathrm{~h}$ at room temperature. The solution was drained, and the beads were washed with $2: 1 \mathrm{MeOH} / \mathrm{H}_{2} \mathrm{O}(4 \times 500 \mathrm{~mL}), \mathrm{MeOH}$ $(4 \times 500 \mathrm{~mL})$, and DMF $(4 \times 500 \mathrm{~mL})$ to yield deprotected resin 5.

Coupling of Resin 5 to 2 (6). Resin 5 (100 g, 15 mmol) was swelled in DMF for $20 \mathrm{~min}$. The solvent was drained, and a solution of 2 (33.56 g, $79.8 \mathrm{mmol}), \mathrm{HOBt}(10.8 \mathrm{~g}$, $79.8 \mathrm{mmol})$, PyBOP (41.52 g, $79.8 \mathrm{mmol}$ ), and DIEA (27.8 $\mathrm{mL}, 159.6 \mathrm{mmol})$ in dry DMF (499 $\mathrm{mL}$ ) was added to the resin. The suspension was allowed to react with gentle shaking for $2 \mathrm{~h}$ at room temperature. The solution was drained, and a fresh solution of $2(33.56 \mathrm{~g}, 79.8 \mathrm{mmol})$, HOBt (10.8 g, $79.8 \mathrm{mmol})$, PyBOP (41.52 g, $79.8 \mathrm{mmol}$ ), and DIEA (27.8 mL, $159.6 \mathrm{mmol})$ in dry DMF (499 mL) was added to the resin. The suspension was allowed to react with gentle shaking for $20 \mathrm{~h}$ at room temperature. The solution was drained, and the beads were washed with DMF $(4 \times 500 \mathrm{~mL})$ to yield resin 6 . The yield of the coupling 
reaction was found to be nearly $100 \%$, based on a quantitative ninhydrin test.

Deprotection of Resin 6 (7). Resin 6 (50 g, 7.5 mmol) was swelled in acetonitrile $(500 \mathrm{~mL})$ for $20 \mathrm{~min}$. The solvent was drained and a solution of $10 \%$ trichloroacetic acid (10 $\mathrm{g}, 61.2 \mathrm{mmol})$ in acetonitrile $(1.0 \mathrm{~L})$ was added to the resin. This suspension was allowed to react with gentle shaking for $30 \mathrm{~min}$ at room temperature. The solution was drained, and a fresh solution of $10 \%$ trichloroacetic acid (10 g, 61.2 $\mathrm{mmol})$ in acetonitrile $(1.0 \mathrm{~L})$ was added to the resin. After $30 \mathrm{~min}$, the solution was refreshed again and allowed to react for an additional $30 \mathrm{~min}(1.5 \mathrm{~h}$ total). The solution was drained, and the resin was washed with acetonitrile $(4 \times$ $500 \mathrm{~mL})$, dichloromethane $(4 \times 500 \mathrm{~mL})$, and DMF $(4 \times$ $500 \mathrm{~mL}$ ). The yield of the deprotection reaction was found to be nearly $100 \%$ based on quantitative ninhydrin test. The charge of resin 7 was determined to be $0.15 \mathrm{mmol} / \mathrm{g}$. This resin was used in subsequent peptoid synthesis reactions.

$\mathrm{N}$-(3-bromobenzyl)-Boc(aminooxy)acetamide (12). To a solution of Boc(aminooxy) acetic acid (503 mg, $2.6 \mathrm{mmol})$ in dry DMF (25 mL) was added 3-bromobenzylamine (493 $\mathrm{mg}, 2.6 \mathrm{mmol})$ and $\mathrm{HOBt}(81 \mathrm{mg}, 0.5 \mathrm{mmol})$. To this stirring solution was added DIC $(0.40 \mathrm{~mL}, 2.6 \mathrm{mmol})$. The solution was allowed to stir for $4 \mathrm{~h}$ at room temperature and then concentrated in vacuo. The residue was purified by silica gel chromatography, eluting with 7:3-6:4 hexane/ethyl acetate, to yield $599 \mathrm{mg}$ (63\%) of $\mathbf{1 2}$ as a clear oil. ${ }^{1} \mathrm{H}$ NMR $\left(\mathrm{CDCl}_{3}, 300 \mathrm{MHz}\right): \delta 8.34($ br s, $1 \mathrm{H}), 7.63(\mathrm{~s}, 1 \mathrm{H}), 7.46-$ $7.14(\mathrm{~m}, 4 \mathrm{H}), 4.47(\mathrm{dd}, J=6.3 \mathrm{~Hz}, 2 \mathrm{H}), 4.37$ (s, 2H), 1.42 (s, 9H). ${ }^{13} \mathrm{C}$ NMR $\left(\mathrm{CDCl}_{3}, 100 \mathrm{MHz}\right): \delta 158.14,140.73$, $130.89,130.59,130.29,126.61,122.81,83.63,76.50,42.51$, 28.25. LRMS (ESI+): $\mathrm{m} / z$ calcd for $\mathrm{C}_{14} \mathrm{H}_{20} \mathrm{~N}_{2} \mathrm{O}_{4} \mathrm{BrNa}^{+}$ $\left[\mathrm{M}+\mathrm{Na}^{+}\right]$382.1, found 382.3.

$\mathrm{N}$-(3-Bromobenzyl)-(aminooxy)acetamide (13). Compound 12 (457 mg, $1.3 \mathrm{mmol})$ was dissolved in a solution of 95:2.5:2.5 trifluoroacetic acid/triisopropylsilane/water $(\mathrm{v} / \mathrm{v} / \mathrm{v})(9.0 \mathrm{~mL})$ and stirred at room temperature for $1 \mathrm{~h}$. The reaction was concentrated in vacuo and purified by reversed-phase HPLC on a C4 column and lyophilized to yield $206 \mathrm{mg}(63 \%)$ of $\mathbf{1 3}$ as a white powder. ${ }^{1} \mathrm{H}$ NMR $\left(\mathrm{MeOD}-d_{4}, 300 \mathrm{MHz}\right): \delta 7.47-7.46(\mathrm{~m}, 1 \mathrm{H}), 7.40-7.37$ (m, 1H), 7.27-7.19 (m, 2H), 1.94 (s, 2H), $1.88(\mathrm{~s}, 2 \mathrm{H}) .{ }^{13} \mathrm{C}$ NMR (CDCl, $100 \mathrm{MHz}): \delta 140.78,130.19,129.99,129.94$, 126.04, 122.02, 71.84, 41.62. LRMS (ESI+): $\mathrm{m} / \mathrm{z}$ calcd for $\mathrm{C}_{9} \mathrm{H}_{12} \mathrm{~N}_{2} \mathrm{O}_{2} \mathrm{Br}^{+}\left[\mathrm{M}+\mathrm{H}^{+}\right]$259.0, found 259.1.

Peptoid Synthesis. The peptoid oligomers were synthesized on an automated peptoid/peptide synthesizer. Each peptoid sequence was prepared following this general procedure.

Two-Step Monomer Addition Cycle. Step 1: Acylation. The resin-bound amine (7, $100 \mathrm{mg}, 0.017 \mathrm{mmol})$ was swelled in $1.0 \mathrm{~mL} \mathrm{DMF}$ for $2 \mathrm{~min}$ and then drained. A $1.2 \mathrm{M}$ solution of bromoacetic acid $(850 \mu \mathrm{L}, 1.0 \mathrm{mmol})$ in DMF was added to this resin at $35^{\circ} \mathrm{C}$, followed by the addition of DIC (185 $\mu \mathrm{L}, 1.1 \mathrm{mmol})$, and DMF $(1.0 \mathrm{~mL})$. The resin was mixed for $20 \mathrm{~min}$, drained, and then washed with DMF $(5 \times 2.0$ $\mathrm{mL}$ ).

Step 2: Displacement. The resin-bound halogen was then displaced with the primary amine submonomer. A $1.0 \mathrm{M}$ solution of the primary amine $(975 \mu \mathrm{L}, 1.0 \mathrm{mmol})$ in $N$-methylpyrrolidinone (NMP) was added to the resin-bound halogen at $35^{\circ} \mathrm{C}$, and this was allowed to react for $20 \mathrm{~min}-2$ $\mathrm{h}$, depending on the length of the peptoid oligomer. After the displacement reaction, the resin was drained and then washed with DMF.

The monomer addition cycle was repeated until the desired oligomer length was achieved.

General Procedure for Side Chain Deprotection and Acetonide Cleavage of Peptoids on Resin 7. Resin-bound peptoid $(6 \mathrm{mg}, 1.0 \mu \mathrm{mol}$ ) was swelled in $200 \mu \mathrm{L}$ methylene chloride for $10 \mathrm{~min}$. The solution was drained, and a cleavage cocktail of 50:49:1 methylene chloride/trifluoroacetic acid (TFA)/water (v/v/v) $(400 \mu \mathrm{L})$ was added to the resin. This suspension was shaken at room temperature for $2-3 \mathrm{~h}$. The solution was drained and the beads were rinsed with 1:1 TFA/ dichloroethane $(\mathrm{v} / \mathrm{v})(3 \mathrm{~mL})$, acetic acid $(3 \mathrm{~mL})$, and water $(3 \mathrm{~mL})$.

General Procedure for Oxidative Cleavage of Peptoids from Resin 7. After side-chain deprotection and acetonide cleavage, the resin $(6 \mathrm{mg}, 1.0 \mu \mathrm{mol})$ was swelled in 5:1 water/acetic acid (v/v) $(200 \mu \mathrm{L})$ for $15 \mathrm{~min}$. The solvent was drained, and a solution of $\mathrm{NaIO}_{4}(0.88 \mathrm{mg}, 4.1 \mu \mathrm{mol})$ in 5:1 water/acetic acid (v/v) $(100 \mu \mathrm{L})$ was added to the beads. The suspension was shaken at room temperature in the dark for $10 \mathrm{~min}$. The cleavage solution was filtered to remove the resin beads and excess $\mathrm{NaIO}_{4}$ was quenched by the addition of dimethyl sulfide ( $10 \mu \mathrm{L}, 136 \mu \mathrm{mol})$. The beads were rinsed with 5:1 water/acetic acid $(\mathrm{v} / \mathrm{v})(2 \times 20 \mu \mathrm{L}$ X $30 \mathrm{~min})$. The rinses were added to the cleavage solution. The solution was centrifuged (4 min at 12,000 rpm), and the supernatant was removed from the solid $\mathrm{I}_{2}$, produced by the reaction of excess $\mathrm{IO}_{4}{ }^{-}$ions with dimethyl sulfide. The supernatant was then evaporated before reaction with amino-oxy compound $\mathbf{1 3}$.

Quantitation and Yield Determination. To determine the yields of the peptoids produced upon cleavage from resin, an absorbance standard line was used. Briefly, the absorbance at $214 \mathrm{~nm}$ of a series of known concentrations of peptoid pentamer 10 was determined. A linear plot of absorbance versus concentration was generated, and the standard line determined from this plot was then used to determine the yields of all peptoid cleavage reactions.

General Procedure for Oxime Formation from Peptoids. After it was oxidatively cleaved from the resin, the peptoid-aldehyde product $(0.11 \mathrm{mg}, 117 \mathrm{nmol})$ was dissolved in a solution of $1: 1$ acetonitrile/100 $\mathrm{mM} \mathrm{NH}_{4} \mathrm{OAc}$, pH 4.5 (100 $\mu \mathrm{L})$. Amino-oxy compound $\mathbf{1 3}(0.045 \mathrm{mg}, 174$ nmol) was added to this solution. The solution was capped and shaken at $37{ }^{\circ} \mathrm{C}$ for $12-20 \mathrm{~h}$. The solvent was evaporated, and the resulting product was dissolved in 1:1 acetonitrile/water (v/v) $(100 \mu \mathrm{L})$ and subjected to MS/MS sequencing analysis.

General Procedure for Acetylation of Resin. If necessary, the Fmoc protecting group was removed from resin using the following procedure.

Beads $(26 \mathrm{mg}$ ) were swelled in $1 \mathrm{~mL}$ DMF for $20 \mathrm{~min}$. The solvent was drained, and a solution of $20 \%$ piperidine in DMF $(1 \mathrm{~mL})$ was added. The beads were shaken at room temperature for $30 \mathrm{~min}$. The solvent was drained, and the 
beads were rinsed with DMF $(5 \times 2 \mathrm{~mL})$. Removal of Fmoc group was found to be quantitative based on a quantitative ninhydrin test.

Resin containing a free amine $(26 \mathrm{mg})$ was swelled in DMF $(1 \mathrm{~mL})$ for $10 \mathrm{~min}$. The solvent was drained and a solution of acetic anhydride $(0.4 \mathrm{M})$ and pyridine $(0.4 \mathrm{M})$ in DMF (1 mL) was added to the beads. This solution was shaken at room temperature for $1 \mathrm{~h}$, after which the solvent was removed. The beads were rinsed with DMF $(5 \times 2 \mathrm{~mL})$ and then dried.

Protein Binding Assay. The resin (approximately $5 \mathrm{mg}$ ) was swelled in DMF $(100 \mu \mathrm{L})$ for $90 \mathrm{~min}$. The DMF was removed and the resin was washed with $\mathrm{dH}_{2} \mathrm{O}(2 \times 100 \mu \mathrm{L}$ for $10 \mathrm{~min})$. The resin was then incubated with a mixture of lung cell lysate from MV522 and NCI H82 cells (500 $\mu$ L of a $4.4 \mathrm{mg} / \mathrm{mL}$ aqueous protein solution) for $1 \mathrm{~h}$ at room temperature. The protein solution was removed and the resin was washed with $1 \times$ TBS $+0.1 \%$ Triton X-100 $(100 \mu \mathrm{L}$ for $5 \mathrm{~min})$ and then with $1 \times \operatorname{TBS}(2 \times 100 \mu \mathrm{L}$ for $5 \mathrm{~min})$. The beads were heated for $5 \mathrm{~min}$ at $100{ }^{\circ} \mathrm{C}$ in protein loading buffer [a 1:2.5:6.5 solution of NuPAGE LDS sample buffer $(4 \times$, Invitrogen)/NuPAGE Reducing Agent $(10 \times$, Invitrogen) $/ 1 \times$ TBS $(40 \mu \mathrm{L})$ to remove any protein that had nonspecifically bound to the resin. These solutions were then analyzed by SDS-PAGE, and visualized using Sypro Ruby protein gel stain (Molecular Probes).

Acknowledgment. We thank Dahzi Tang for initial MS/ MS spectra and helpful advice. We thank Michael Connolly and Byoung-Chul Lee for peptoid synthesis advice. We also thank Joel Berger, John Fuller, and Thomas Horn for helpful discussions.

Supporting Information Available. MS/MS spectra of compounds 16-22. Purities and yields for compounds 15$\mathbf{2 3}$ This material is available free of charge via the Internet at http://pubs.acs.org.

\section{References and Notes}

(1) Thompson, L. A.; Ellman, J. A. Chem. Rev. 1996, 96, 555600.

(2) Lebl, M.; Krchnak, V.; Sepetov, N. F.; Seligmann, B.; Strop, P.; Felder, S.; Lam, K. S. Biopolymers 1995, 37, 177-198.

(3) Lam, K. S.; Lebl, M. Methods: A Companion to Methods in Enzymology 1994, 6, 372-380.

(4) Bachhawat-Sikder, K.; Kodadek, T. J. Am. Chem. Soc. 2003, 125, 9550-9551.

(5) Lam, K. S.; Lebl, M.; Krchnak, V. Chem. Rev. 1997, 97, $411-448$.

(6) Lam, K. S.; Liu, R. W.; Miyamoto, S.; Lehman, A. L.; Tuscano, J. M. Acc. Chem. Res. 2003, 36, 370-377.

(7) Alluri, P. G.; Reddy, M. M.; Bachhawat-Sikder, K.; Olivos, H. J.; Kodadek, T. J. Am. Chem. Soc. 2003, 125, 1399514004.

(8) Reddy, M. M.; Bachhawat-Sikder, K.; Kodadek, T. Chem. Biol. 2004, 11, 1127-1137.

(9) Naffin, J. L.; Han, Y.; Olivos, H. J.; Reddy, M. M.; Sun, T.; Kodadek, T. Chem. Biol. 2003, 10, 251-259.

(10) Kodadek, T.; Reddy, M. M.; Olivos, H. J.; Bachhawat-Sikder, K.; Alluri, P. G. Acc. Chem. Res. 2004, 37, 711-718.

(11) Simon, R. J.; Kania, R. S.; Zuckermann, R. N.; Huebner, V. D.; Jewell, D. A.; Banville, S.; Ng, S.; Wang, L.; Rosenberg, S.; Marlowe, C. K.; Spellmeyer, D. C.; Tan, R.; Frankel, A. D.; Sant, D. V.; Cohen, F. E.; Bartlett, P. A. Proc. Natl. Acad. Sci. U.S.A. 1992, 89, 9367-9371.
(12) Murphy, J. E.; Uno, T.; Hamer, J. D.; Cohen, F. E.; Dwarki, V.; Zuckermann, R. N. Proc. Natl. Acad. Sci. U.S.A. 1998, 95, 1517-1522.

(13) Figliozzi, G. M.; Goldsmith, R.; Ng, S. C.; Banville, S. C.; Zuckermann, R. N. Methods Enzymol. 1996, 267, 437-447.

(14) Burkoth, T. S.; Fafarman, A. T.; Charych, D. H.; Connolly, M. D.; Zuckermann, R. N. J. Am. Chem. Soc. 2003, 125, 8841-8845.

(15) Miller, S. M.; Simon, R. J.; Ng, S.; Zuckermann, R. N.; Kerr, J. M.; Moos, W. H. Drug Dev. Res. 1995, 35, 20-32.

(16) Zuckermann, R. N.; Martin, E. J.; Spellmeyer, D. C.; Stauber, G. B.; Shoemaker, K. R.; Kerr, J. M.; Figliozzi, G. M.; Goff, D. A.; Siani, M. A.; Simon, R. J.; Banville, S. C.; Brown, E. G.; Wang, L.; Richter, L. S.; Moos, W. H. J. Med. Chem. 1994, 37, 2678-2685.

(17) Garcia-Martinez, C.; Humet, M.; Planells-Cases, R.; Gomis, A.; Caprini, M.; Viana, F.; De la Pena, E.; Sanchez-Baeza, F.; Carbonell, T.; De Felipe, C.; Perez-Paya, E.; Belmonte, C.; Messeguer, A.; Ferrer-Montiel, A. Proc. Natl. Acad. Sci. U.S.A. 2002, 99, 2374-2379.

(18) Thompson, D. A.; Chai, B. X.; Rood, H. L. E.; Siani, M. A.; Douglas, N. R.; Grantz, I.; Millhauser, G. L. Bioorg. Med. Chem. Lett. 2003, 13, 1409-1413.

(19) Heizmann, G.; Hildebrand, P.; Tanner, H.; Ketterer, S.; Pansky, A.; Froidevaux, S.; Beglinger, C.; Eberle, A. N. J. Recept. Signal Transduction Res. 1999, 19, 449-466.

(20) Wentworth, P.; Janda, K. D. Curr. Opin. Biotech. 1998, 9, 109-115.

(21) Yan, B. Curr. Opin. Chem. Biol. 2002, 6, 328-332.

(22) Swali, V.; Bradley, M. Anal. Commun. 1997, 34, H15-H18.

(23) Hughes, I.; Hunter, D. Curr. Opin. Chem. Biol. 2001, 5, $243-$ 247.

(24) Chen, J. K.; Lane, W. S.; Brauer, A. W.; Tanaka, A.; Schreiber, S. L. J. Am. Chem. Soc. 1993, 115, 12591-12592.

(25) Liu, R. W.; Lam, K. S. Anal. Biochem. 2001, 295, 9-16.

(26) Boeijen, A.; Liskamp, R. M. J. Tetrahedron Lett. 1998, 39, 3589-3592.

(27) Brenner, S.; Lerner, R. A. Proc. Natl. Acad. Sci. U.S.A. 1992, 89, 5381-5383.

(28) Czarnik, A. W. Curr. Opin. Chem. Biol. 1997, 1, 60-66.

(29) Barnes, C.; Balasubramanian, S. Curr. Opin. Chem. Biol. 2000, 4, 346-350.

(30) Affleck, R. L. Curr. Opin. Chem. Biol. 2001, 5, 257-263.

(31) Needels, M. C.; Jones, D. G.; Tate, E. H.; Heinkel, G. L.; Kochersperger, L. M.; Dower, W. J.; Barrett, R. W.; Gallop, M. A. Proc. Natl. Acad. Sci. U.S.A. 1993, 90, 10700-10704.

(32) Kerr, J. M.; Banville, S. C.; Zuckermann, R. N. J. Am. Chem. Soc. 1993, 115, 2529-2531.

(33) Ohlmeyer, M. H. J.; Swanson, R. N.; Dillard, L. W.; Reader, J. C.; Asouline, G.; Kobayashi, R.; Wigler, M.; Still, W. C. Proc. Natl. Acad. Sci. U.S.A. 1993, 90, 10922-10926.

(34) Nestler, H. P.; Bartlett, P. A.; Still, W. C. J. Org. Chem. 1994, 59, 4723-4724.

(35) Baldwin, J. J.; Burbaum, J. J.; Henderson, I.; Ohlmeyer, M. H. J. J. Am. Chem. Soc. 1995, 117, 5588-5589.

(36) Youngquist, R. S.; Fuentes, G. R.; Lacey, M. P.; Keough, T. J. Am. Chem. Soc. 1995, 117, 3900-3906.

(37) Ni, Z. J.; Maclean, D.; Holmes, C. P.; Murphy, M. M.; Ruhland, B.; Jacobs, J. W.; Gordon, E. M.; Gallop, M. A. J. Med. Chem. 1996, 39, 1601-1608.

(38) Fitch, W. L.; Baer, T. A.; Chen, W. W.; Holden, F.; Holmes, C. P.; Maclean, D.; Shah, N. H.; Sullivan, E.; Tang, M.; Waybourn, P.; Fischer, S. M.; Miller, C. A.; Synder, L. R. J. Comb. Chem. 1999, 1, 188-194.

(39) Nicolaou, K. C.; Pfefferkorn, J. A.; Mitchell, H. J.; Roecker, A. J.; Barluenga, S.; Cao, G. Q.; Affleck, R. L.; Lillig, J. E. J. Am. Chem. Soc. 2000, 122, 9954-9967.

(40) Winssinger, N.; Harris, J. L.; Backes, B. J.; Schultz, P. G. Angew. Chem., Int. Ed. 2001, 40, 3152-3155.

(41) Blackwell, H. E.; Perez, L.; Schreiber, S. L. Angew. Chem., Int. Ed. 2001, 40, 3421-3425. 
(42) Liu, R. W.; Mark, J.; Lam, K. S. J. Am. Chem. Soc. 2002, 124, 7678-7680.

(43) Song, A. M.; Zhang, J. H.; Lebrilla, C. B.; Lam, K. S. J. Am. Chem. Soc. 2003, 125, 6180-6188.

(44) Brummel, C. L.; Lee, I. N. W.; Zhou, Y.; Benkovic, S. J.; Winograd, N. Science 1994, 264, 399-402.

(45) Fitzgerald, M. C.; Harris, K.; Shevlin, C. G.; Siuzdak, G. Bioorg. Med. Chem. Lett. 1996, 6, 979-982.

(46) Swali, V.; Langley, G. J.; Bradley, M. Curr. Opin. Chem. Biol. 1999, 3, 337-341.

(47) Gibson, C.; Sulyok, G. A. G.; Hahn, D.; Goodman, S. L.; Holzemann, G.; Kessler, H. Angew. Chem., Int. Ed. 2001, $40,165-169$.

(48) Zambias, R. A.; Boulton, D. A.; Griffin, P. R. Tetrahedron Lett. 1994, 35, 4283-4286.

(49) Aebersold, R.; Mann, M. Nature 2003, 422, 198-207.

(50) Heerma, W.; Versluis, C.; de Koster, C. G.; Kruijtzer, J. A.; Zigrovic, I.; Liskamp, R. M. Rapid Commun. Mass Spectrom. 1996, 10, 459-464.

(51) Heerma, W.; Boon, J. P. J. L.; Versluis, C.; Kruijtzer, J. A. W.; Hofmeyer, L. J. F.; Liskamp, R. M. J. J. Mass Spectrom. 1997, 32, 697-704.

(52) Ruijtenbeek, R.; Versluis, C.; Heck, A. J. R.; Redegeld, F. A. M.; Nijkamp, F. P.; Liskamp, R. M. J. J. Mass Spectrom. 2002, 37, 47-55.

(53) Deng, L.; Mrksich, M.; Whitesides, G. M. J. Am. Chem. Soc. 1996, 118, 5136-5137.

(54) Fruchart, J. S.; Gras-Masse, H.; Melnyk, O. Tetrahedron Lett. 1999, 40, 6225-6228.

(55) Melnyk, O.; Fruchart, J. S.; Grandjean, C.; Gras-Masse, H. J. Org. Chem. 2001, 66, 4153-4160.

(56) Guarna, A.; Guidi, A.; Machetti, F.; Menchi, G.; Occhiato, E. G.; Scarpi, D.; Sisi, S.; Trabocchi, A. J. Org. Chem. 1999, 64, 7347-7364.
(57) Lemieux, G. A.; Bertozzi, C. R. Trends Biotechnol. 1998, $16,506-513$.

(58) Rose, K. J. Am. Chem. Soc. 1994, 116, 30-33.

(59) Shao, J.; Tam, J. P. J. Am. Chem. Soc. 1995, 117, 38933899.

(60) Schnolzer, M.; Jedrzejewski, P.; Lehmann, W. D. Electrophoresis 1996, 17, 945-953.

(61) Lane, S. J.; Pipe, A. Rapid Commun. Mass Spectrom. 2000, 14, 782-793.

(62) Lorthioir, O.; Carr, R. A. E.; Congreve, M. S.; Geysen, M. H.; Kay, C.; Marshall, P.; McKeown, S. C.; Parr, N. J.; Scicinski, J. J.; Watson, S. P. Anal. Chem. 2001, 73, 963970.

(63) Wang, X. B.; Zhang, J. H.; Song, A. M.; Lebrilla, C. B.; Lam, K. S. J. Am. Chem. Soc. 2004, 126, 5740-5749.

(64) Hwang, S. H.; Lehman, A.; Cong, X.; Olmstead, M. M.; Lam, K. S.; Lebrilla, C. B.; Kurth, M. J. Org. Lett. 2004, 6, 3829-3832.

(65) According to Rapp Polymere, the company that manufactures TentaGel beads, beads that are $280-320 \mu \mathrm{m}$ in diameter are defined as "macrobeads". Although larger bead sizes are available, we found this bead size to be the most useful for our studies.

(66) In our hands, we had no problems with the TentaGel beads, as long as we did not change the solvent polarity too quickly. For instance, the beads would exhibit some cracking if subjected to water immediately after being swelled in methylene chloride. However, we found that by gradually increasing the polarity (i.e., from $100 \%$ methylene chloride to $1: 1$ methylene chloride/methanol to $100 \%$ methanol to $100 \%$ water), we could eliminate bead cracking.

CC0501460 